\title{
TROPOLOGICAL SPACE: THE IMAGINARY SPACE OF FIGURATION*
}

Keywords: microtropes; macrotropes; mega (meta)tropes; tropological space

\begin{abstract}
The paper is devoted to the concept of tropological space, introduced by Michel Foucault in 1966 and alluded to in Hayden White's tropics of discourse $(1973,1978,2000)$, but never described in any detail in literary semantics or linguistic stylistics. The author presents her theory of a triple functional subdivision of stylistic figures and, consequently, of tropes (micro-, macro- and mega (meta)-level of description) and relates it to a gradually expanding tropological space of particular figures, their chains and groupings within a text. The author postulates that tropological space, the imaginary space created through figuration, is a sub-space of the Wittgensteinian logical space as well as a sub-space of textual / discursive space. Although the discussion refers mostly to literary texts, tropol$o g y$ - a branch of stylistics / poetics / rhetoric makes generalizations valid for the study of all kinds of texts / discourses. Figuration is assumed here to be an inherent feature of conceptual and linguistic expression. Finally, the author raises a methodological query as to the ontological status of tropological space, opting for the approach which treats it as a peculiar kind of semantic space rather than a mere metaphoric term.

The discussion is based mostly on the Anglo-American studies on figuration (K. Burke, H. White, P. de Man, J. Hillis Miller, G. Hartman) that are rooted in the neo-classical rhetoric and writings of G. Vico. This line of thinking draws its philosophical inspiration from the European hermeneutics of P. Ricœur, the Foucaultian theory of discourses and the Derridean deconstructionist ideas on the operation of language. The author brings additionally into consideration the conception of artistic space propagated by the Russian semiotic tradition and V. N. Toporov (1983/2003) in particular.
\end{abstract}

* Main tenets of this article were presented during an international seminar "Linguistics \& Literary Studies: Interfaces, Encounters, Transfers" organized by the Freiburg Institute for Advanced Studies at Albert-Ludwigs-Universität, Freiburg, Germany in July 2009. The hottest debate concerned the ontological status of tropological space, that is the issue of its allegedly metaphorical status; cf. section 6 . 


\section{Introduction}

Tropology (called also tropics by White 1978/1985), the study of figuration as a conceptual and linguistic phenomenon present in all kinds of discourses, has enjoyed a substantial revival in Anglo-American stylistics, poetics and rhetoric over the last four decades. With its roots in ancient studies of oratory and poetics (Aristotle, Quintilian, Cicero) and a growing interest in its issues displayed by the neo-classical rhetoric in the Renaissance (Peter Ramus), the study of patterns of figuration found a real impetus in the writings of Giambattista Vico $(1725,1730,1744)$, which has strongly influenced modern literary criticism and literary semantics, to mention only Kenneth Burke (1945/1962) and his followers. Postmodern and deconstructionist critics - Paul de Man, Geoffrey Hartman, James Hillis Miller - as well as philosophers of various orientations - Michel Foucault (1966), Paul Ricœur (1975), Jacques Derrida (1977) - have all contributed considerably to the realization of a now unquestionably recognized fact that human language is irreducibly figurative and that the amount of troping, that is a departure from the literal, is a question of scale running across all human texts / discourses, from works marked with the highest artistic style to casual colloquial exchanges. This current of research has found its most mature shape in the writings of Hayden White $(1975,1978 / 1985,2000)$ who on the occasion of his in-depth analysis of historiographic discourse and historical narrative has formulated a neo-Vichian (and neo-Burkian) theory of tropes as pervasive modes of human thought and discursive expression. If we add to this the influential cognitive theory of conceptual metaphor authored by George Lakoff, Mark Johnson and Mark Turner (Lakoff and Johnson 1980, Lakoff and Turner 1989), elaborated since by the world-wide community of scholars (cf. Worth 1994, Kövecses 2002, Stockwell 2002, Semino 2008), the opinion that the related fields of stylistics / poetics / rhetoric have been granted a new life seems to be fully substantiated. ${ }^{1}$

In what follows, I would like to make the following claims. First, I want to limit our analysis to tropes proper, namely semantic stylistic figures. In this, I assume that all figures of traditional and modern stylistics can be analysed according to the linguistic level of their description, which lands us with the classification of such devices into: a) phonetic, b) morphological, c) syntactic, d) semantic (tropes) and e) graphic, allowing for areas of overlap between these categories (cf. ChrzanowskaKluczewska 2003, 2004a). In my concentrating on traditionally conceived tropes (after Quintilian, qtd. in Lausberg 1960/1971), I depart from a wider conception of tropes cherished by White, who treats them generically as a broad category of any deviation from the literal, with figures referring to particular classes of tropes. On my approach, 'figure' is taken to be a generic hyperonym, with 'tropes' being only a realisation of figuration at the semantic level. The epitome of so conceived tropes is the great foursome of Vico, Burke and White, to wit: metaphor, metonymy, synecdoche and irony.

Against the pessimistic title of an essay of Ricœur's “The decline of rhetoric: tropology" (in Ricœur 1975/2008: 49-73). 


\section{Tropological space as sub-space of logical space}

My second assumption is that tropes, as representatives of "imaginative figuration" (in de Man's wording 1986/2006: 34), each of them separately but also in various combinations, create their own space which I refer to as tropological (cf. Chrzanowska-Kluczewska 2003: 211, 2004a: 69, 78). The term tropological space comes from Foucault (1966/2009: 126), who also refers to it as rhetorical space (p. 174). ${ }^{2}$ The space of figuration so conceived refers vastly to things imagined rather than real and, in this capacity, constitutes a sub-region of logical space envisioned by Ludwig Wittgenstein in Tractatus logico-philosophicus (1922).

We have, then, to distinguish at least three kinds of space:

1. physical (normal, ordinary space of our bodily and mental experience),

2. geometrical (abstract space of mathematical reasoning),

3. logical (called also semantic space of our collective imaginarium).

Wittgenstein's idea of logischer Raum can be summarized in a sequence of the following claims: "3.411 In geometry and logic alike a place is a possibility [...]" (Wittgenstein 1922/2008: 21). "2.013 Each thing is, as it were, in a space of possible states of affairs" (p. 7). "3.4 A proposition determines a place in logical space" (p. 21). "1.13 The facts in logical space are the world" (p. 5). In the 1970s the schools of American analytical philosophy and modal logic elaborated the idea of the space of all possibilities imaginable to human mind ${ }^{4}$ in connection with the birth of possible worlds semantics (among others, Saul Kripke and David Lewis). The citation from Karel Lambert and Bas van Fraassen (1970: 2) is a straightforward exposition of the above-quoted Wittgensteinian ideas: "Associated with the language is a logical space in which each individual in the domain of discourse has a location. Each predicate is assigned a region of logical space [...]".

Logical space is both conceptual and linguistic, at first private and cherished by one particular mind but soon supra-individual, expressed linguistically, socially accessible and shared by a given community. In such understanding it is a continuation of the lecta of the Stoics and of Gottlob Frege's senses. According to Umberto Eco, in the non-private guise, such space is always a "cultural construct" and a "semiotic product" (Eco 1990: 66).

Compared with physical space, logical space is by much more powerful, genuinely unbound and infinite (cf. Chrzanowska-Kluczewska 2007). Since it contains all possibilities pooled together by the collective human imagination, it consists of an infinite number of possible states of affairs that combine into possible worlds.

2 The equation of the 'tropological' with the 'rhetorical' quality of conceptual and linguistic space finds also support in de Man's idea, developed in extenso in Allegories of reading (1979), that human language is inherently tropical and persuasive at the same time. Figuration, then, becomes merged with rhetoric. Actually, this seems to be a tenet shared by all the deconstructionist thinking (cf. also Hillis Miller 1986).

3 I have rearranged the order of quotes purposefully to make the progression of reasoning clearer to the reader.

4 Called also the "space of speculative thought" by Ricœur (1975/2008: 371). 
Eco (2006: 110) refers to it as "a vertiginous idea of the plurality of Possible Worlds". In this connection, I want to bring into our discussion a completely different research tradition, deeply preoccupied with the issue of artistic space, in the person of Vladimir N. Toporov, a representative of the Moscow School of Semiotics. Continuing a long line of formalistic and semiotic studies on poeticity and literariness carried on most prominently by Viktor Shklovsky, Roman Jakobson and Yuri Lotman, Toporov (1983/2003) describes artistic space as "strengthened":

In the same way as the mythopoetic space is "stronger" than ordinary space (living, geometrical, physical, etc.), the inner space of an artistic space is "stronger" than any outer space. [...] The inner (textual) space of freedom is incomparably more complex, more saturated and energizing than outer space. [...] It is a pure creation [...]. Such a space of a "great" text is linked to an infinite number of interpretations, owing to which the text can live "forever" and everywhere (Toporov 1983/2003: 94-95, transl. ECh-K).

The citation above perfectly characterizes not only logical space but specifically the artistic space of figuration, highlighting its interpretative potential.

Already Lewis (1979) notices that logical space can be affected and transformed by particular modalities and propositional attitudes. Richard Rorty (1991) adds that metaphoricity likewise can expand logical space towards still unknown regions of cognition. Seemingly, metaphor is treated here as an umbrella-term for all kinds of tropes but in our discussion below they will soon regain their own face as cocreators of tropological, artistic space.

\section{Tropological space as subspace of textual / discourse space}

Tropes usually function within texts and discourses that call to life their own space, often fictional. The literature on possible worlds / text worlds / discourse worlds that support such texts is extremely rich and terminologically inconsistent (cf., among others, Enkvist 1989, Fish 1980, 1989, Werth 1999, Stockwell 2002, ChrzanowskaKluczewska 2009). Trying to reduce the ideas expounded by the above-quoted authors to a common denominator, I propose to treat textual space as an interplay of two spaces: the authorial space of the text-creator complemented by the paraspace of the reader / interpreter (the term comes from Fish). The fact that we badly need a cooperation of the author and the reader lies in a constitutive characteristics of all text worlds and the texts that represent them, namely their underdetermination. All texts by their very nature (dictated by the exigencies of the economy and informativity of language) are to a certain extent incomplete / gappy. Roman Ingarden (1931/1973) referred to this striking feature of literary creation as "spots of indeterminacy", while de Man (1971) as "areas of blindness". It is the role of the reader / interpreter to fill in the gaps in an appropriate way, avoiding the excesses of under- or over-interpretation (cf. Eco 1990). This activity, which can be seen as an on-going dialogue between the text-creator and the text-receiver can also be analysed as a joint semantico-pragmatic 
game played by the author and the text itself on one hand and the succession of readers on the other (cf. Chrzanowska-Kluczewska 2004b).

Since no text ever really functions in the void, it has been suggested that we need a larger construct, termed discourse world or discourse space, which is the actual physical, linguistic, social and cultural space in which both the author and the prospective audiences function. Discourse space signifies, in fact, the immersion of a chunk of logical space that supports a particular text within the ordinary, historical, ideological and semiotic space of both the author and the interpreters. For this reason Peter Stockwell (2002), who has elaborated the theoretical constructs propagated by Paul Werth $(1994,1999)$, refers to discourse worlds as cognitively enriched textual worlds, a more humane version of austere possible worlds of modal logicians.

It should by now be obvious that tropological space, which is figurative and rhetorical in nature, constitutes a sub-space of fictional / literary / artistic / semiotic space, in a word - a portion of what Fish calls the cosmos of literature. Yet, as the deconstructionist analyses and the claims of cognitive linguists have convincingly demonstrated, figuration is an all-pervasive phenomenon. If so, tropological space will, of necessity, be attached to non-literary texts and discourses as well, the fact that finds corroboration in discourse studies related to the language of politics, religion, science, medicine, law, media and last, but not least, dreams (cf. Semino 2008).

\section{The space of micro-, macro- and mega (meta)-tropes}

A consecutive methodological assumption that I would like to develop below is the recognition of the fact that all stylistic and rhetorical figures, and tropes in particular, possess their own syntactic scope and construe their functional domains of operation within a text / discourse. What I postulate is close in spirit to functional scopes of operation of such linguistic elements as quantifiers, modal operators or operators of negation. Such functional domains are syntactic, semantic and conceptual at the same time, in the sense that operators work within certain structural limits related to a corresponding semantic structure backed by an appropriate mental representation.

For some time now (Chrzanowska-Kluczewska 2003, Chrzanowska-Kluczewska 2004a, Chrzanowska-Kluczewska 2009a) I have been propagating the following triple subdivision of figures and of tropes in particular:

1. Microtropes, the semantic figures of traditional stylistics and rhetoric, whose functional domain covers phrases (including unaccompanied head words) and at most sentences. Such small tropes have been the focus of interest of the majority of traditional analyses. The first list of such tropes, covering thirteen or fourteen items was drawn by Quintilian (cf. Lausberg 1060/2002).

2. Macrotropes, which can also be classified as big semantic figures, organize considerably larger stretches of a text. Already antiquity knew and took pleasure in the so-called extended similes (Homeric) or extended metaphors. In English poetry several passages from Paradise lost by John Milton are structured by chains of 
metonymies and synecdoches, Emily Dickinson's poem 712 "Because I Could Not Stop for Death" is in its entirety an extended metaphor, and Ted Hughes' poem "Thistles" is a nice case of a macro-simile aptly combined with a macropersonification (cf. Chrzanowska-Kluczewska 2004a: 68).

3. Mega (meta)tropes, contrary to micro- and macrotropes that are always overt, belong to the tacit layer of the text. They are large text-forming strategies that have to be recognized by the Model or Ideal Reader, to use Eco's terms. The idea of applying stylistic figures to the holistic analysis of discourse has its roots in the well-known article "Two aspects of language and two types of aphasic disturbances" by Roman Jakobson (1956), who postulated the two regulatory dimensions of language -metaphoric and metonymic - present in various types of texts in a broad semiotic and not only exclusively linguistic understanding. Consequently, metaphor and metonymy have been promoted to the rank of large textual models or rhetorical strategies. The qualification mega-is chronologically later: it appears in Werth's ponderings on conceptual space and its reflections in discourse, embedded in the cognitive paradigm. Werth, like other cognitivists, deals exclusively with metaphor, but it is worth to quote him direct:

It is not enough to say [...] that metaphors simply cluster. The fact that metaphors can also be sustained, as a kind of 'undercurrent', over an extended text allows extremely subtle conceptual effects to be achieved. I will refer to the sustained metaphorical undercurrent discussed above as megametaphors (Werth 1999: 323).

The clusters of metaphors that Werth mentions correspond to figurative chains mentioned above, while the terms 'sustained' and 'undercurrent' point to the fact that megatropes function at a covert level of interpretation. In my previous articles (Chrzanowska-Kluczewska 2003, Chrzanowska-Kluczewska 2004a) I decided to refer to this deepest or highest tropological level as metalevel. I was influenced by the writings of Foucault and White in particular, but also by the deconstructionist critics, who pointed out that large figures of discourse are often 'self-aware', that is, auto-reflexive, capable of talking about themselves. In this meta- understanding tropes often refer not to a particular reality (actual or fictional) but to the text itself, which they transcend and comment on. Thus, megatropes can but do not necessarily have to be metatropical.

In what concerns tropological space, it seems natural to claim that it corresponds in size to the functional domain of a given figure. Consequently, microtropes will be spatially most limited, whereas macrotropes will correspond to an extended tropological space, which ultimately culminates in the vast space at the level of megafiguration. Additionally, the conceptual space of all figures operative in a given text / discourse combines into a sort of collective space of figuration.

As far as the number of megatropes goes, the Jakobsonian duet of metaphor and metonymy, visible also in the cognitive approach (though metaphor seems to be a predominant mode of thought and expression), is definitely too modest. Already the Renaissance rhetoric, the "poetical logic" of Vico, as well as Burke's (1945/1962) and White's tropics rely on the tetrad of master-tropes. I have decided to extend 
this list considerably, in the light of suggestions disseminated by post-modernist philosophers and critics (items 5 - 15):

1. metaphor - the figure of similarity and difference, of making the world familiar,

2. metonymy - the figure of objective contiguity (broadly conceived neighbourhood),

3. synecdoche - the figure of essentiality and generalization,

4. irony - the figure of the transposition of truth and falsehood (according to White, metatropical par excellence and the most sophisticated of the four),

5. antithesis - the figure of oppositeness and antinomy,

6. inversion - the figure which unites two contrasting states,

7. chiasmus - the figure of reversal, viz. the transformation of concepts into their contraries,

8. catachresis - the figure of a broadly understood semantic abuse and logical transgression,

9. paronomasia - the figure of generalized inexact imitation, of unsuccessful mimesis,

10. euphemia - the figure of toning down, mitigating and lessening unpleasant effects,

11. suppression - the figure of polite or deceitful omission, passing over, becoming silent,

12. exaggeration - the figure of megahyperbole, overstatement,

13. anomaly - the figure of purposeful estrangement, defamiliarization, deautomatization,

14. allegory - the figure of a symbolic narration on moralizing or generally valid themes,

15. simile - the figure of direct comparison and similarity.

The list is tentative and probably not exhaustive. ${ }^{5}$ Although it is theoretically open (contrary to the set of small figures of traditional stylistics and poetics which is practically closed), it should be borne in mind that the exigencies of the so-called explanatory power and methodological elegance of this taxonomy require that it should not be overly expanded. It is worth remembering that Quintilian had at most fourteen representatives of small tropes in his classification.

In my first article on metatropes (Chrzanowska-Kluczewska 2003) I postulated fifteen metatropes, with the last position occupied by mythization. However, on second thoughts, I removed this item from my subsequent list (Chrzanowska-Kluczewska 2004a). The reason was that mythization seems to be a narratological strategy rather than a trope proper. Instead, after some qualms signalled to me by other researchers, I have decided to include simile among suitable candidates for mega (meta-)tropes. Although metaphor is largely based on comparison, it is frequently dissimilarity rather than resemblance that has to be taken into consideration in interpreting certain metaphors, particularly far-fetched, catachrestic constructions. My lists have been drawn according to suggestions by Vico (1725/2002, 1744/1984), Burke (1945/1962), Jakobson (1956), Foucault (1966/2009), Barthes (1970/1999, 1971/1994), White (1973, 1978/1985, 2000), Shklovsky (in Shukman 1977), de Man (1979a, 1979b, 1986/2006), Hartman (1985) and Hillis Miller (1986). 
In order to illustrate an intricate interplay of the three levels of figuration, I am quoting below a Christina Rossetti poem "Tempus fugit”:

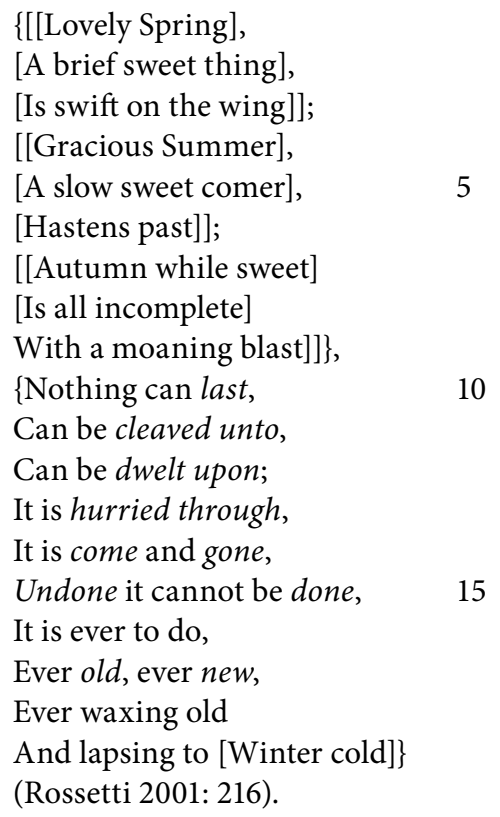

By means of square bracketing I indicate functional domains of microtropes. Thus, the first sentence (which occupies lines 1-3) contains three micrometaphoric descriptions: spring is, allegedly, personified through the ascription of the quality lovely, which is additionally strengthened by capitalization of the head noun. In fact, all four seasons of the year mentioned chronologically in the poem are seemingly instances of personification. Yet, the consecutive noun phrase $a$ brief sweet thing is an instance of reification, which has an obvious de-personifying effect; in consequence we are no longer sure whether Spring is a person or an object. In turn, the third micrometaphor, operative within the verbal phrase, likens spring to a winged creature, possibly a bird. From the structural point of view, these three micrometaphors fill up the entire sentential domain. From the semantic viewpoint, they display an unobvious wavering between personification, reification and animization (theriomorhism?). Lines 4-6, built as a parallel construction to lines 1-3, play on the similar functional domains: gracious Summer looks like a personification again, which in this case is strengthened by the second noun phrase a slow sweet comer and the predicative microstructure hastens past. Like before, these three micrometaphors occupy their particular phrasal domains, filling - in sum - a sentential domain. Lines 7-9 contain a nominal and a verbal domain occupied by a metaphor, arguably personifying, showing autumn as qualified by such attributes as sweet, incomplete and moaning. The last quality, ascribed to blast is a case of metaphorical transfer. The chain of metaphors that organize the first part of the poem are a case of macrometaphoric construction that spans the space of three sentences (and which I signal by braces). The second part of the 
poem, much more literal, has a different tropological arrangement. The dominant macrofigure is the play on opposites. Microfigures, viz. contraries and contradictories (highlighted by means of italics) are either participles or adjectives: the chain of last (verb), cleaved unto and dwelt upon contrasts with hurried through, come contrasts with gone, undone with done, old with new. The macrotrope of oppositeness ends, in the last line, with another personifying metaphor Winter cold. Yet, in addition to the micro- and macrotropological level of structuring and semantics, there functions a covert level of interpretation ("undercurrent" to use Werth's wording again) that invokes the mega-level of troping. This includes, at least the megametaphor of the ruinous and relentless flow of time (signalled by the graphic shape of the poem as well) and the double antithesis of young vs. old age, of life vs. death. Additionally, the four seasons of the year stand symbolically for the four stages of human life and, by their clear generalizing character, achieve the status of allegory. Within the nineteen lines of her poem, Rossetti - in a masterful way - makes recourse to the triple level of troping. ${ }^{6}$ The interplay of functional domains understood both syntactically and semantically is reflected in the slowly expanding tropological space, which grows steadily from the micro- to macro- to megaspace of figuration, at first overtly given to the reader, then calling on his / her literary and tropological competence in recognizing the tacit level of the most inclusive space of large textual figures.

\section{Perspectivization and spatial transformations within tropological space}

It can be expected that tropological space, like any other space, will be related to a specific point of view, which we can refer to as figurative perspective. Applying Roger Fowler's (1986) taxonomy of perspective in literary texts, which subsumes: 1) physical, 2) psychological and 3) ideological viewpoint, we can claim that figuration will be involved in all three types of perspectivization. Still, it seems to me that tropological space is mostly concerned with psychological (emotional) perspective and, more rarely, with the ideological perspective, visible especially well in strongly rhetorically oriented discourses (political, religious, etc.).

More specifically, some tropes can be broadly classified as the figures of familiarity. Several authors in the field have emphatically stressed the epistemic role of metaphor as the device of "taming" the world around us. Yet, it has to be remembered that apart from the familiarizing metaphor, most frequently funded on similarity, we still have at our disposal the strained metaphor called catachresis, whose role is to bring together disparate objects and play on differences. Thus catachresis, which is a figure of anomaly, should be related to a defamiliarizing and often shocking perspective, meant to shake our stereotypical views and combat the boredom of routine thinking. The psychological role of metonymy (discussed by Vico, White and Toporov,

Werth's $(1994,1999)$ treatment of metaphor is a "double-layered conceptualization" (Werth 1994: 79) that operates at the sentence and discourse level. My analysis postulates a triple layering at the phrasal / sentential level (overt), at the textual level (overt) and at the discursive level (covert). 
among others) is to dissect the homogeneous world of similarities into objectively related parts. The contiguity of terms that construe metonymy must be understood very broadly, in terms of spatial, temporal, causal, teleological, etc. conceptual adjacency. Thus, the metonymical perspective can at first seem defamiliarizing but, in the long run, it teaches us how to recognize the intricacy of relationships holding among objects and individuals in our universe. Additionally, Toporov pointed out that due to metonymy poetic space becomes condensed and dramatized, quoting Boris Pasternak, for whom metonymy and not metaphor was a dominant figure (Toporov 1983/2003: $34 \mathrm{fn} .28$ ). In turn, the synecdochical perspective is that of discovering salient features of all entities and, as a result, of making us able to generalize. What metonymy has shattered, synecdoche is supposed to reconstruct, by projecting parts onto wholes and building things general out of essential and particular features.

The three tropes mentioned above were described as "naive" by Vico. Irony, a figure of distance and meta-descriptions which closes the Vichian tropological circle (cf. Chrzanowska-Kluczewska 2009a), is often described as a trope of sophistication, which evolves relatively late in terms of developmental psychology. Depending on the particular perspective it creates, it can function as a figure of deception but also of self-mockery and self-understanding.

Along the lines suggested above for the four master-tropes, we could describe possible strategies of perspectivization for the remaining megatropes. The subject has not been studied in any detail so far and the limited scope of this paper relegates the discussion to the future studies of the potential of tropological space. But whatever perspective we are bound to accept, it should be realized and remembered that each of them is a kind of foreshortening and manipulation with data, a sort of oblique vision accepted to the detriment of other viewpoints (cf. Ingarden 1931/1973, Toporov 1983/2003, Chrzanowska-Kluczewska 2007). All this reminds us that we constantly need to switch our perspectives and try to understand alien viewpoints. The intercourse with fictional discourse has a strong educational role to play in this respect.

Toporov points to another aspect, which may be referred to as manipulation of space in artistic discourse. His idea is that language, especially figurative, deforms the extra-textual space (ordinary space) in the process of transporting or converting it into intra-textual space. The typology he has proposed mentions the following strategies of affecting space, which are very obviously tropically induced:

- interiorization

- compression

- broadening

- explosion

- condensation

- ossification

- annihilation.

In line with Toporov's idea of "semantic management of space" (Toporov 1983/ 2003: 30), I posit to refer to the manipulation with space and perspective with the 
help of figurative devices as the tropological management of textual / discursive space. In this process we assimilate, adapt and cultivate the space open to us owing to our limitless conceptual and linguistic resources. The cognitive and epistemic function of tropological space, hinted at not only by linguists, literary semanticists, critics and philosophers mentioned in this article but also by psychologists (Sigmund Freud, Jean Piaget, Jacques Lacan - cf. White 1978/1985, 2000 and Chrzanowska-Kluczewska 2009a) deserves definitely more reflection than it has received so far.

\section{Space in its own right or a spatial metaphor?}

Of real methodological interest remains the question whether tropological space is only a metaphor useful as a descriptive device in literary semantics and criticism or whether it is a very special sort of mental, conceptual and linguistic space. It is worth quoting George Sefler, who commented on the Wittgensteinian conception of logischer Raum as follows: "Logical space is a metaphorical device indicative of the totality of possible structural combinations of objects by which propositions map out reality" (Sefler 1974: 67). If he was right, we could produce an analogous description of tropological space as a totality of possible combinations of functional domains created successively by small, big and large figures of our thought and language. But does it really make sense to explain the conceptual and linguistic potential of metaphors and other tropes by invoking another metaphor, indeed a new meta-metaphorical level of description? I would rather opt for the second solution, namely treating tropological space, as well as textual and discursive space of which it is a part, as space in its own right, a subspace of communication in which social and individual imagination merge and which is shared culturally or even cross-culturally (cf. Eco 2006: 11, 15 on "obsessive metaphors" common to humanity). Romolo Runcini, representing a similar sociological approach to literary texts, aptly notices: "This is the infinite power of communication. It is the word - the keystone of a creative / cognitive process which transforms the over-familiar world of everyday experience..." (Runcini 1998: 25). The figurative word above all, it could be added.

\section{Sources}

Rossetti Ch. 1995/2001. Tempus fugit. - Selected poems of Christina Rossetti. [Introduction and notes by K. McGowran]. Ware, Herfordshire: 216.

\section{References}

Barthes R. 1970/1999. S / Z. Warszawa.

Barthes R. 1971/1994. Une idée de recherche. - Marty E. (ed.) Euvres complètes [vol. II]. Paris: $1218-1221$.

Burke K. 1945/1962. A grammar of motives. Cleveland, New York. 
Chrzanowska-Kluczewska E. 2003. Mikrotropy, makrotropy, metatropy. - Stylistyka XII: 207-224.

Chrzanowska-Kluczewska E. 2004a. Microtropes, macrotropes, metatropes. - AAA - Arbeiten aus Anglistik und Amerikanistik 29. 1: 65-80.

Chrzanowska-Kluczewska E. 2004 b. Language-games: pro and against. Kraków.

Chrzanowska-Kluczewska E. 2007. Logical/textual space vs. physical space. - Freeman D. C., Baş I. (eds.) Challenging the boundaries [PALA II]. Amsterdam, New York.

Chrzanowska-Kluczewska E. 2009a. Philosophical underpinnings of metatropes: is Vico's tropological circle a vicious circle? - Chrzanowska-Kluczewska E., Szpila G. (eds.) In search of (non)sense. Newcastle u. Tyne: 102-114.

Chrzanowska-Kluczewska E. 2009b. Possible worlds - text worlds - discourse worlds in a dialogic context. - Chrzanowska-Kluczewska E., Gołda-Derejczyk A. (eds.) The contextuality of language and culture. Bielsko-Biała: 157-171.

Derrida J. 1977. Of grammatology. Baltimore.

Eco U. 1990. The limits of interpretation. Bloomington, Indianapolis.

Eco U. 2002/2006. On literature. London.

Enkvist N. E. 1989. Connexity, interpretability, universes of discourse, and text worlds. Sturé A. (ed.) Possible worlds in humanities, arts and sciences. Proceedings of Nobel Symposium 65 (1986). Berlin: 162-186.

Fish S. 1980. Is there a text in this class? Cambridge, MA.

Fish S. 1989. Doing what comes naturally. Change, rhetoric and the practice of theory in literature and legal studies. Durham, NC.

Foucault M. 1966/2009. The order of things. An archaeology of the human sciences. London, New York.

Fowler R. 1986. Linguistic criticism. Oxford, New York.

Hartman G. 1985. Easy pieces. New York.

Hillis Miller J. 1986. On edge: the crossways of contemporary criticism. - Eaves M., Fischer M. (eds.) Romanticism and contemporary criticism. Ithaca, New York [Polish transl. 2000. Krawędź: współczesne badania literackie na rozstajach. - Nycz R. (ed.) Dekonstrukcja w badaniach literackich. Gdańsk: 143-182].

Ingarden R. 1931/1973. The literary work of art [transl. G. G. Grabowicz]. Evanston, ILL.

Jakobson R. 1956. Two aspects of language and two types of aphasic disturbances. - Jakobson R., Halle M. (eds.) Fundamentals of language [= Janua Linguarum 1]. 'S-Gravenhage: 53-82.

Kövecses Z. 2002. Metaphor. A practical introduction. Oxford.

Lakoff G., Johnson M. 1980. Metaphors we live by. Chicago.

Lakoff G., Turner M. 1989. More than cool reason. A field guide to poetic metaphor. Chicago, London.

Lambert K., van Fraassen B. 1970. Meaning relations, possible objects, and possible worlds. Lambert K. (ed.) Philosophical problems in logic. Some recent developments. Dordrecht: 1-19.

Lausberg H. 1960. Handbuch der literarischen Rhetorik. München [Polish transl. 2002. Retoryka literacka. Podstawy wiedzy o literaturze. Bydgoszcz].

Lewis D. 1979. Attitudes de dicto and de se. - Philosophical Review 88.4: 513-543.

de Man P. 1971. Blindness and insight: essays in the rhetoric of contemporary criticism. Oxford. de Man P. 1979a. Allegories of reading. Figural language in Rousseau, Nietzsche, Rilke, and Proust. New Haven.

de Man P. 1979b. Autobiography as de-facement. - Modern Language Notes 94: 919-930.

de Man P. 1986/2006. The resistance to theory. Minneapolis, London. 
Ricœur P. 1975/2008. The rule of metaphor. London, New York.

Rorty R. 1991. Objectivity, relativism and truth: essays on Heidegger and others [vol. II]. Cambridge.

Runcini R. 1978. The social and individual imagination. - Sosień B. (ed.) Lespace, la théâtralité et limaginaire. Kraków: 23-25.

Semino E. 2008. Metaphor in discourse. Cambridge.

Shukman A. 1977. Literature and semiotics. A study of the writings of Yu. M. Lotman. Amsterdam, New York, Oxford.

Stockwell P. 2002. Cognitive poetics. An introduction. London, New York.

Toporov V. N. 1983/2003. [Prostranstvo i tekst] Przestrzeń i rzecz. Kraków.

Vico G. 1725/2002. The first New Science [ed. and transl. by L. Pompa]. Cambridge.

Vico G. 1744/1984. The New Science of Giambattista Vico [unabridged translation of the $3^{\text {rd }}$ edition 1744 by T. G. Bengin and M. H. Fisch]. Ithaca, London.

Werth P. 1994. Extended metaphor - a text-world account. - Language and Literature 3.2: 79-103.

Werth P. 1999. Text worlds: representing conceptual space in discourse. Harlow.

White H. 1973. Metahistory. The historical imagination in nineteenth-century Europe. Baltimore, London.

White H. 1978/1985. Tropics of discourse. Essays in cultural criticism. Baltimore, London.

White H. 2000. Figural realism. Studies in the mimesis effect. Baltimore, London.

Wittgenstein L. 1922/2008. Tractatus logico-philosophicus. London, New York. 